\title{
Making the Break: The Ethics of Disassociation and Exclusion in a Value-Oriented Educational Association
}

\author{
Maughn Gregory ${ }^{1}$
}

Acts of disassociation and exclusion are risky but often necessary to either disrupt, or preclude one's culpability in an immoral situation. This thesis is applied to the case of the membership of Brigham Young University (BYU), which has written policies prohibiting LGBTQ faculty and students, in the National Network for Educational Renewal (NNER), which holds education for social justice as a moral ideal. It is concluded that the NNER should take some kind of exclusionary action against BYU, and five moral objections that have been raised to this conclusion are answered. It is suggested that if the NNER takes no exclusionary action toward BYU, other member institutions may be morally obliged to disassociate from it. [Article copies available for a fee from The Transformative Studies Institute.E-mail address: journal@transformativestudies.org Website: http://www.transformativestudies.org (02009 by The Transformative Studies Institute. All rights reserved.]

KEYWORDS: LGTBQ, Discrimination, Disassociation, Exclusion, Religion, Social Justice.

A lawyer for a multinational corporation resigns her position, on being pressured to broker what she considers an exploitative labor contract with under-privileged employees in a developing country.

One friend declines with careful explanation the invitation to a dinner party to which another friend has been conspicuously uninvited after having recently come out of the closet.

\footnotetext{
${ }^{1}$ Maughn Gregory, Ph.D., J.D. is Associate Professor of Educational Foundations at Montclair State University, where he also directs the Institute for the Advancement of Philosophy for Children and Project THISTLE: Thinking Skills in Teaching and Learning. Address correspondence to: Maughn Gregory, Associate Professor of Educational Foundations, Montclair State University, Upper Montclair, NJ 07043; tel: 973.655.7049; e-mail: gregorym@montclair.edu.
} 